\title{
SEASONAL BEHAVIOUR OF KERATINOPHILIC FUNGI ISOLATED FROM PARKS SOIL IN MILAN
}

\author{
(Comportamiento estacional de hongos queratinofílicos \\ aislados en suelos de parques en Milán)
}

\author{
N. Solari, M. Guglielminetti \& G. Caretta \\ Department of Land Ecology and Terrestrial Environment, Section of Mycology, \\ University of Pavia. Via S. Epifanio, 14-27100 Pavia, Italia. \\ Tel. +390382504867; e-mail: nadia.s12@libero.it
}

Key words: Keratinophilic fungi, dermatophytes, parks soil.

Pallabras clave: Hongosqueratinofilicos, dermatofitos, suelos de parques

\begin{abstract}
Soil samples collected from 10 parks in Milan were examined for the presence of keratinophilic fungi by the Orr's hair baiting technique. The organisms isolated and their frequency were as follows: Arthroderma uncinatum and its anamorph Keratinomyces ajelloi were dominant and recovered from $22.5 \%-43.7 \%$ and $40 \%-50 \%$ of the soil samples collected in summer and winter respectively. Myceliophthora vellerea was isolated in $31.2 \%$ of the samples, particularly in winter, Microsporum gypseum in winter (20\%) and Trichophyton terrestre (10\%) in summer. Chrysosporium keratinophilum (16.2\% in summer and $18.7 \%$ in winter) C. indicum (15\% s- $23.7 \%$ w), C. pannicola $(5 \%$ s $-37 \%$ w). Aphanoascus fulvescens was isolated in summer (23.7\%). Among the cycloheximide-resistant keratinophilic fungi Alternaria alternata (27.5\% s - 33.7\% w), Paecilomyces lilacinus $(26.2 \% \mathrm{~s}-18.7 \% \mathrm{w})$ and Acremonium strictum $(8.7 \% \mathrm{~s}-20 \% \mathrm{w})$ also were observed. The distribution of the different species is discussed.
\end{abstract}

\section{INTRODUCTION}

Studies on the incidence of keratinophilic fungi in the Italian soils have been reported from agricultural and public gardens and parks in many countries (1-4). These fungi, according to Garrett's terminology, are a substrate group and the final colonisers in all soils (5). They have the ability to digest keratin in vitro (6-9) in their saprophytic state and some may invade tissues in vivo and provoke welldefined infections in animals and humans (10).

Several species displayed distinct limitations in their distribution; some species are ubiquitous, others peculiar to the region and others rare $(11,12)$.

\section{RESUMEN}

Se examinaron muestras de suelo procedentes de 10 parques de Milán para determinar la presencia de hongos queratinofilicos utilizando la técnica de Orr. Los organismos aislados y su frecuencia fueron: Arthroderma uncinatum y su anamorfo Keratinomyces ajelloi fueron dominantes y se recuperaron desde un 22,5\%-43,7\% y 40\%$50 \%$ de las muestras de suelo colectadas en verano e invierno respectivamente.Myceliophthora vellerea fue detectada en el 31,2\% de las muestras, particularmente en invierno, Microsporum gypseum en invierno (20\%) y Trichophyton terrestre (10\%) en verano. Chrysosporium keratinophilum ( $16.2 \%$ en verano y $18.7 \%$ en invierno) C. indicum (15\% v-23.7\% i), C. pannicola (5\% v - 37\% i). Aphanoascus fulvescens fue aislado en verano (23.7\%). Entre los hongos queratinofílicos resistentes a la cicloheximida, se presentó Alternaria alternata (27.5\% v $33.7 \%$ i), Paecilomyces lilacinus (26.2\% v - 18.7\% i) y Acremonium strictum (8.7\% v-20\% i). Se discute la distribución de las diferentes especies.

The present survey was undertaken to acquire information on the natural occurrence and seasonal distribution of keratinophilic fungi in park area and ex zoological garden soils from the metropolitan area in Milan.

\section{MATERIALS AND METHODS}

Eighty soil samples were taken from 10 randomly selected sites (8 samples for each park) in Milan's metropolitan area. Fungi were isolated by the hair baiting technique as recorded by Vanbreuseghem (13) and modified by Orr (14). The soil was collected in late summer in the year 
2001 and in winter sampling in the year 2002. Each sample was composed of soil collected in a $5 \mathrm{~m}^{2}$ area, just below (2$3 \mathrm{~cm}$ ) the ground surface after the removal of superficial vegetative material and other debris from the surface of the soil. A sterile glass Petri dish (2 x $150 \mathrm{~mm})$ was half-filled with $40 \mathrm{~g}$ of soil sample and sterile human hair, horsehair and pieces of feathers (approximately $2-3 \mathrm{~cm}$ long), were scattered on the surface of the soil samples. The soil was then moistened with about $15 \mathrm{ml}$ of sterile water containing $0.05 \mathrm{mg} / \mathrm{ml}$ chloramphenicol and cycloheximide at a $1.5 \mathrm{~g} / \mathrm{L}$ concentration and incubated at room temperature. The Petri dishes were checked regularly ( destilled water being added as required) over a period of 8 weeks for any growth of keratinophiles. When mycelial growth was visible on the hair under a stereoscopic microscope a part of this growth was transferred onto potato dextrose agar (PDA) and the isolates were identified.

Identifications were made directly from the growth on the baiting plates especially when the teleomorphic isolates were obtained. Fungi were identified by their macro and micromorphological characters in lacto-phenol, cotton blue or lacto-acid fuchsin $1 \%$.

In every soil sample each fungal species was counted only once even if it was present on all the keratinous substrate.

\section{RESULTS}

The keratinophilic fungi isolated from soil collected in the metropolitan area of Milan in summer sampling and winter sampling are listed in tables 1 and 2 . As shown in tab. 1 (summer) 186 isolates of 18 species of fungi and 2 varieties classified in 8 different genera, were identified. In winter 173 isolates of 14 species of fungi and 2 varieties classified in 8 genera were identified.

The anamorphic and teleomorphic forms of some of the fungi were reported separately because the two states of these fungi did not always occur together. Arthroderma uncinatum and its anamorphic state, Keratinomyces ajelloi, were predominant and both were isolated from $22.5 \%$ $43.7 \%$ and from $40 \%-50 \%$ of the soil samples collected in summer and in winter respectively. Ctenomyces serratus was rarely isolated but its anamorph Myceliophthora vellerea (=Chrysosporium asperatum) was frequently isolated from soil collected, particularly in winter (31.2\%).

Among the geo-keratinophilic fungi, anamorphs Microsporum gypseum complex was isolated from soil collected in winter (20\%) and Trichophyton terrestre (10\%) from soil sampled in summer. Among the zoophilic Microsporum species, M. canis was the only zoophilic dermatophyte isolated from a soil sample at Solari's park. Species of Chrysosporium found in the order of their relative frequency were: $\boldsymbol{C}$. keratinophilum (16.2\% in summer and
$18.7 \%$ in winter), C. indicum (15\% and 23.7\%), C. pannicola (5\% and $3.7 \%$ ), C. merdarium (only in winter 5\%) and occasionally $\boldsymbol{C}$. tropicum and $\boldsymbol{C}$. carmichaelii. In numerous plate the teleomorph Aphanoascus fulvescens developed in summer (23.7\%). In some plates the teleomorphs $\boldsymbol{A}$. clatrathus, $A$. reticulisporus, $A$. terreus and $A$. verrucosus were observed.

Among non Onygenales, the cycloheximideresistant keratinophilic fungi the most frequently recorded species present in the majority of the soil samples collected in summer and winter were respectively Alternaria alternata (27.5\% - 33.7\%), Paecilomyces lilacinus (26.2\% - 18.7\%), Acremonium strictum (8.7\% - 20\%).

The fungi only occasionally recorded were Phialophora cyclaminis (6.2\%), Clonostachys rosea (7.5\%), Sepedonium chrysospermum (7.5\%) and Pochonia chlamydosporia (=Verticillium chlamydosporium) $(7.5 \%)$.

\section{DISCUSSION}

A distinctive feature of this survey is the dominance in the fungal spectrum of $\boldsymbol{A}$. uncinatum and its anamorph $\boldsymbol{K}$. ajelloi in all garden soils collected in the metropolitan area of Milan . Being a widespread soil inhabitant, this species has been recovered from soil in Belgium (15) in Italy $(2-4,16)$, New Zealand (17) in soil from the metropolitan area of Detroit (18). Domsch et al. (19) list birds' nests, hair and skin scraping as sources. Rippon (20) reports it from cattle, dogs and squirrels but it is a rare pathogen of humans; human cutaneous cases are rare (21). In culture, the formation of sexual structures is inhibited at temperatures above $25^{\circ} \mathrm{C}$ and there is no growth at $37^{\circ} \mathrm{C}$. According to Marples, the high incidence of $\boldsymbol{K}$. ajelloi in New Zealand is related for to the populations of sheep; it seems possible that the constant increments of wool, which the soil receives, serve as an enrichment to the substrate for $\boldsymbol{K}$. ajelloi. The association of this species with strongly acid soils is suggestive for Marples (17) and its widespread dominance may be related to the $\mathrm{pH}$ of the substrate, to the temperature and the proportion of direct sunlight on the habitat. This author finds it curious that $\boldsymbol{K}$. ajelloi is absent from the soil samples of the Pacific Islands. The rarity of domestic mammals in the Pacific Island could contribute to the scarcity of $\boldsymbol{K}$. ajelloi in these soils.

Among geophilic dermatophytes whose pathogenicity is universally recognised we have isolated $\boldsymbol{M}$. gypseum, M. cookei and $M$. canis. The anamorph Microsporum gypseum complex was isolated in eight of the ten parks in Milan. This was the most frequently found species from the soil of public gardens and parks in Rome (3) from sand boxes in Turin (4) and from park soil in Pavia $(1,2)$. M. gypseum has been well documented as a pathogen in man and animals where the source of most infections is 
Table 1 Member of Onygenales isolated from soils in the area of Milan in summer.

\begin{tabular}{|c|c|c|c|c|c|c|c|c|c|c|c|c|c|}
\hline $\begin{array}{c}\text { Localities sampled } \\
n^{\circ} \text { of samples examined : } 80\end{array}$ & $\begin{array}{l}\mathbf{A} \\
\mathbf{8}\end{array}$ & $\begin{array}{l}\mathbf{B} \\
\mathbf{8}\end{array}$ & $\begin{array}{l}\mathrm{C} \\
\mathbf{8}\end{array}$ & $\begin{array}{l}\mathbf{D} \\
\mathbf{8}\end{array}$ & $\begin{array}{l}\mathbf{E} \\
8\end{array}$ & $\begin{array}{l}\mathbf{F} \\
\mathbf{8}\end{array}$ & $\begin{array}{l}\mathbf{G} \\
8\end{array}$ & $\begin{array}{c}\mathbf{H} \\
\mathbf{8}\end{array}$ & $\begin{array}{l}\text { I } \\
8\end{array}$ & $\begin{array}{l}\mathbf{L} \\
\mathbf{8}\end{array}$ & $\begin{array}{c}\text { Total } \\
\text { isobtes }\end{array}$ & \multicolumn{2}{|c|}{ Percentage on: } \\
\hline Fungal taxa: & & & & & & & & & & & & samples & isolates \\
\hline $\begin{array}{l}\text { Aphanoascus clatrathus Cano \& } \\
\text { Guarro }\end{array}$ & & & & & & & 1 & & & & 1 & 1.25 & 0.54 \\
\hline $\begin{array}{l}\text { Aphanoascus fulvescens (Cooke) } \\
\text { Apinis }\end{array}$ & 2 & 1 & 4 & 3 & 3 & & 1 & 1 & 1 & 3 & 19 & 23.75 & 10.21 \\
\hline Aphanoascus teticulisporus & & 1 & & 1 & & 1 & & 1 & 1 & 1 & 6 & 7.5 & 3.23 \\
\hline $\begin{array}{l}\text { Aphanoascus terreus (Randhawa \& } \\
\text { Sandhu) Apinis }\end{array}$ & & & & & & & & 1 & & & 1 & 1.25 & 0.54 \\
\hline $\begin{array}{l}\text { Aphanoascus verrucosus Cano \& } \\
\text { Guaro }\end{array}$ & & 1 & & & & & & 1 & & & 2 & 2.5 & 1.07 \\
\hline $\begin{array}{l}\text { Arthroderma quadrifidum Dawson } \\
\& \text { Gentles }\end{array}$ & & & 1 & & & & & & & & 1 & 1.25 & 0.54 \\
\hline $\begin{array}{l}\text { Athroderma uncinatum Dawson \& } \\
\text { Gentles }\end{array}$ & 3 & & 2 & 3 & & 3 & 1 & 2 & 1 & 3 & 18 & 22.5 & 9.68 \\
\hline $\begin{array}{l}\text { Chrysosporium carmichaelï van } \\
\text { Oorschot }\end{array}$ & 1 & & & & & & & & & & 1 & 1.25 & 0.54 \\
\hline $\begin{array}{l}\text { Chtysosporium indicum (Randhawa } \\
\text { \& Sandhu) Garg }\end{array}$ & 1 & & & & 1 & 2 & 2 & 2 & 2 & 2 & 12 & 15 & 6.45 \\
\hline $\begin{array}{l}\text { Chrysosporium ker atinophilum } \\
\text { (Frey) Carmichael }\end{array}$ & 1 & & & 2 & 2 & 2 & 2 & 2 & 1 & 1 & 13 & 16.25 & 6.99 \\
\hline $\begin{array}{l}\text { Chrysosporium pannicola (Corda) } \\
\text { van Oorschot \& Stalpers }\end{array}$ & & & 3 & & & & & & 1 & & 4 & 5 & 2.15 \\
\hline Chrysosporium sp. & 2 & 2 & 1 & 2 & 3 & & 2 & 2 & 2 & 3 & 19 & 23.75 & 10.21 \\
\hline $\begin{array}{l}\text { Chrysosporium tropicum } \\
\text { Carmichael }\end{array}$ & & 2 & & & & & & & & & 2 & 2.5 & 1.07 \\
\hline Qenomyces serratus Eidam & & & 2 & & & & & & & & 2 & 2.5 & 1.07 \\
\hline $\begin{array}{l}\text { Geomyces pannorum (Link) Sigler } \\
\text { \& Carmichael var. asperulatus } \\
\text { (Sigler \& Carmichael) van Oorschot }\end{array}$ & & & & 1 & & 1 & 1 & 1 & & & 4 & 5 & 2.15 \\
\hline $\begin{array}{l}\text { Geomyces pannorum (Link) Sigler } \\
\text { \& Carmichael var. pannorum }\end{array}$ & & & & & & & & & 1 & & 1 & 1.25 & 0.54 \\
\hline Wicrosporum cookei A jello & 3 & 1 & & & & & & & & & 4 & 5 & 2.15 \\
\hline $\begin{array}{l}\text { Wicrosporum gypseum (Bodin) } \\
\text { Guiart \& Grigorakis }\end{array}$ & 3 & & & 2 & 2 & 2 & 3 & 2 & 2 & & 16 & 20 & 8.6 \\
\hline $\begin{array}{l}\text { Wycelioph thora vellerea (Sacc. \& } \\
\text { Spegazzini) van Oorschot }\end{array}$ & 2 & 2 & 4 & 1 & 1 & 3 & & 2 & 2 & & 17 & 21.25 & 9.14 \\
\hline Keratinomyces ajelloi Vanbreu. & 4 & 1 & 3 & 4 & 4 & 4 & 4 & 3 & 4 & 4 & 35 & 43.75 & 18.82 \\
\hline Trichophyton terrestre Durie \& Frey & 2 & & & 1 & & & 3 & 1 & 1 & & 8 & 10 & 4.3 \\
\hline TOTAL & & & & & & & & & & & 186 & & \\
\hline
\end{tabular}

A. Porta Venezia park (ex ZOO), B. Piazza Sempione park， C. Giardini park, D. Indipendenza park, E: Insubria square park, F. Martini square park, G. Marinai d'Italia square park, H. Solari square park, I. Cantore square park, L: Aquileia square park.

the soil or exposure to soil-borne propagules of this fungus (22). M. cookei has occasionally been isolated in Milan and occur in the soil samples of the ex-zoological park at Porta Venezia. This widely distributed species has been isolated from soil, and hair of wild animals.
Two strains of $\boldsymbol{M}$. canis were isolated from the park soil of Solari in Milan during the winter. This zoophilic species has exceptionally been isolated from soil by Vanbruseghem's hair baiting technique (22-25). It infects a wide variety of lower animal especially cats, and humans readily 
Tab. 2. Member of Onygenales isolated from soils in the area of Milan in winter.

\begin{tabular}{|c|c|c|c|c|c|c|c|c|c|c|c|c|c|}
\hline $\begin{array}{c}\text { Localities sampled } \\
\mathrm{n}^{\circ} \text { of samp les examined : } 80\end{array}$ & $\begin{array}{c}\mathbf{A} \\
\mathbf{8}\end{array}$ & $\begin{array}{l}\mathbf{B} \\
\mathbf{8}\end{array}$ & $\begin{array}{l}\mathrm{C} \\
\mathbf{8}\end{array}$ & $\begin{array}{l}\mathbf{D} \\
\mathbf{8}\end{array}$ & $\begin{array}{l}\mathbf{E} \\
\mathbf{8}\end{array}$ & $\begin{array}{l}\mathbf{F} \\
\mathbf{8}\end{array}$ & $\begin{array}{l}\mathbf{G} \\
\mathbf{8}\end{array}$ & $\begin{array}{l}\mathbf{H} \\
\mathbf{8}\end{array}$ & $\begin{array}{l}\mathbf{I} \\
\mathbf{8}\end{array}$ & $\begin{array}{l}\text { L } \\
8\end{array}$ & \begin{tabular}{|c|} 
Total \\
isolates
\end{tabular} & \multicolumn{2}{|c|}{ Percentage on: } \\
\hline Species isolated: & & & & & & & & & & & & samples & isolates \\
\hline $\begin{array}{l}\text { Aphanoascus fulvescens (Cooke) } \\
\text { Apinis }\end{array}$ & 2 & & & & & 1 & & & & & 3 & 3.75 & 1.78 \\
\hline $\begin{array}{l}\text { Arthroderma uncinatum Dawson \& } \\
\text { Gentles }\end{array}$ & 4 & 4 & 4 & 4 & 3 & 3 & 1 & 4 & 3 & 2 & 32 & 40 & 18.93 \\
\hline $\begin{array}{l}\text { Chrysosporium indicum (Randhawa } \\
\text { \& Sandhu) Garg }\end{array}$ & 1 & 2 & 3 & & 3 & 2 & 1 & 3 & 2 & 2 & 19 & 23.75 & 11.24 \\
\hline $\begin{array}{l}\text { Chrysosporium keratinophilum } \\
\text { (Frey) Carmichael }\end{array}$ & 1 & 2 & & 1 & 1 & 3 & & 4 & 2 & 1 & 15 & 18.75 & 8.88 \\
\hline $\begin{array}{l}\text { Chrysosporium merdarium (Link } \\
\text { Grev) Camichael }\end{array}$ & & & 1 & 1 & & 2 & & & & & 4 & 5 & 2.37 \\
\hline $\begin{array}{l}\text { Chrysosporium pannicola (Corda) } \\
\text { Oorschot \& Stalpers }\end{array}$ & & & & & & 2 & & & 1 & & 3 & 3.75 & 1.78 \\
\hline $\begin{array}{l}\text { Chrysosporium tropicum } \\
\text { Carmichael }\end{array}$ & & & & & & & & & & 1 & 1 & 1.25 & 0.59 \\
\hline Ctenomyces serratus Eidam & & & & & & & & & 1 & & 1 & 1.25 & 0.59 \\
\hline $\begin{array}{l}\text { Geomyces pan notum (Link) Sigler } \\
\text { \& Carmichael var. asperulatus } \\
\text { (Sigler \& Carmichael) van Oorschot }\end{array}$ & 1 & & & & & 1 & & & & & 2 & 2.5 & 1.88 \\
\hline $\begin{array}{l}\text { Geomyces pan norum (Link) Sigler } \\
\text { \& Carmichael var. pannorum }\end{array}$ & & & & & & & & & 1 & & 1 & 1.25 & 0.94 \\
\hline Microsporum canis Bodin & & & & & & & & 2 & & & 2 & 2.5 & 1.18 \\
\hline Microsporum cookei A jello & 2 & & & & & & & 1 & & 2 & 5 & 6.25 & 2.96 \\
\hline $\begin{array}{l}\text { Microsporum gypseum (Bodin) } \\
\text { Guiart \& Grigorakis }\end{array}$ & 3 & 1 & & 3 & 2 & 2 & 2 & 2 & 1 & & 16 & 20 & 9.47 \\
\hline $\begin{array}{l}\text { Hycelioph thora vellerea (Sacc. \& } \\
\text { Spegazzini) van Oorschot }\end{array}$ & 4 & 3 & 3 & 2 & 2 & 4 & & 4 & 2 & 1 & 25 & 31.25 & 14.79 \\
\hline Keratinomyces ajelloi Varbreu. & 4 & 4 & 4 & 4 & 4 & 4 & 4 & 4 & 4 & 4 & 40 & 50 & 23.67 \\
\hline Trichophyton terrestre Durie \& Frey & 2 & & & 1 & & & & & & & 3 & 3.75 & 1.78 \\
\hline TOTAL & & & & & & & & & & & 169 & & \\
\hline
\end{tabular}

get infections through direct contact with infected animals. M. canis was isolated from soil sample collected in the garden of San Gallicano hospital in Rome (3).

The geophilic species, which may be considered as true inhabitants, it is interesting to note the highest occurrence of Myceliophthora vellerea in all soil park; the teleomorph Ctenomyces serratus was only rarely isolated. The occurrence of the anamorphic state rather than the teleomorphic state is probably a reflection of the heterothallic nature of the species. This species is worldwide and has a strong predilection for feathers but it has also been found on dung and in soil and it is considered a soil saprophytic fungus.

Special attention should be paid to the species closely related to dermatophytes, particularly Aphanoascus, Chrysosporium, Geomyces and Trichophyton, which were rather common in the garden and park soils. Their potential as human or animal pathogens has been recognised.

T. terrestre is able to infect domestic pets (26) or humans (27). A. fulvescens and some Chrysosporium such as $\boldsymbol{C}$. keratinophilum, $\boldsymbol{C}$. tropicum and $\boldsymbol{C}$. pannicola are the most frequent fungi isolated from domestic or wild mammals or birds (28). Van Oorschot (29) suggested that $\boldsymbol{C}$. keratinophilum represented the anamorph of $A$. fulvescens, but for Cano and Guarro (30) the teleomorph of $\boldsymbol{C}$. keratinophilum discovered by keratin-baiting of soil in Spain has been described as Aphanoascus keratinophilus, forming ascomata on cultura only on oatmeal medium. Among the non dermatophytic filamentous keratinophilic fungi recorded in this survey, Alternaria alternata, Paecilomyces lilacinus, Acremonium strictum and Verticillium chlamydosporium were frequently found in 
park soil. They are common saprophytes in soil and plant debris. Cutaneous infection due to Alternaria species have been reported from several parts of the world, as the species of the genera Acremonium and Paecilomyces in human cases of cutaneous and pulmonary infections (31).

Results obtained in this survey for keratinophilic fungi in the soil from the gardens and parks of Milan, show that some genera and species are always present and that the less frequent species survive in the soil. Some seasonal variation in the presence of keratinophilic fungi in soil has been detected.

\section{REFERENCES}

1.- Caretta, G. \& Piontelli, E. (1975). Isolation of keratinophilic fungi from soil in Pavia, Italy. Sabouraudia. 13:33-37

2.- Caretta, G.; Mangiarotti, A. \& Piontelli, E. (1992). Keratinophilic fungi isolated from soil of Italian parks in the province of Pavia. Eur. J. Epidem. 8:330-339

3.- Mercatini, R.; Marsella, R.; Caprilli, F. \& Dovgiallo, G. (1980). Isolation of dermatophytes and correlated species from the soil of public gardens and parks in Rome. Sabouraudia. 18:123-128

4.- Filipello Marchisio. V. (1986). Keratinolytic and keratinophililic fungi of children's sandpits in the city of Turin. Mycopathologia 94:163-172

5.- Griffin, D. M. (1972). Ecology of soil fungi. Chapman \& Hall (eds) London, pp. 193

6.- English, M. P. (1963). The saprophytic growth of keratinophilic fungi on keratin. Sabouraudia 2:115-130.

7.- English, M. P. (1965). The saprophytic growth of nonkeratinophilic fungi on keratinized substrata, and a comparation with keratinophilic fungi. Trans. Br. mycol. Soc. 48:219-234

8.- English, M. P. (1968). The developmental morphology of the perforating organs of dermatophytes. Sabouraudia. 6:218-227

9.- Filipello Marchisio, V. (2000). Keratinophilic fungi: their role in nature and degradation of keratinic substrates. In: Kushwaha, R K $\mathrm{S}$ \& Guarro, J (eds) Biology of dermatophytes and other keratinophilic fungi. Rivista Iberoamericana de Micologia. Bilbao, Spain, pp. 86-92.

10.- Richardson, M. \& Edward, M. (2000). Model systems for the study of dermatophyte and non-dermatophyte invasion of human keratin. In: Kushwaha, R K S \& Guarro, J (eds). Biology of dermatophytes and other keratinophilic fungi. Rev. Iberoam. Micol. Bilbao, Spain, pp. 115-121

11.- Otcenasek, M.; Dvorak, J. \& Kunert, J. (1967). Geographic distribution of the geophilic dermatophytes in the soil. Mycopath. Mycol. appl. 31:151-162

12.- Sympanya, M. F. (2000). Dermatophytes: their taxonomy, ecology and pathogenicity. In: Kushwaha, R K S \& Guarro, J (eds) Biology of dermatophytes and other keratinophilic fungi. Rev. Iberoam.Micol. Bilbao, Spain, pp. 1-12

13.- Vanbreuseghem, R. (1952). Technique biologique pour l'isolement des dermatophytes du sol. Ann. Soc. belge Med. trop. 32:173-178

14.- Orr, G. F. (1969). Keratinophilic fungi isolated from soils by a modified hair bait technique. Sabouraudia. 7:129-134

15.- Ajello, L.; Varsavsky, E. \& Delvingt, W. (1965). Keratinophilic fungi from Belgian soil. Trans. Br. mycol. Soc. 48: 417-421

16.- Pinetti, P. \& Lostia, A. (1966). Primi risultati sistemici sulla presenza e sulla distribuzione di miceti cheratinofili nel suolo di alcune zone della Sardegna. Gior. Ita. Derm. 107:1093-1114

17.-Marples, M J. (1965). The distribution of keratinophilic fungi in soils from New Zealand, and from two Polynesian Islands. Mycopathologia. 25:361-372

18.- Bajwa, P. \& Jeffries, C. D. (1986). The keratinophilic fungi in soil from the Detroit metropolitan area. Mykosen. 29:267-271

19.- Domsch, K. H.; Gams, W. \& Anderson, T H. (1980). Compendium of soil fungi. Acad. Press. London. U. K., Vol. 1,II.

20.- Rippon, J W. (1988). Medical Mycology. The Pathogenic Fungi and the Pathogenic Actinomycetes. $3^{\text {rd }}$ ed. W. B. Saunders Company, Philadelphia.

21.- Diniz, L.; Souza Filho, J. B. \& Vitoria, L. C. da. (1991). Dermatofitose por Trichophyton ajelloi em ser humano. Anais Bras. Derm. 66:275-276

22.- De Vroey, C. H. (1970). Contribution à l'étude des dermatophytes et d'autres Gymnoascacées. Ann. Soc. belge Méd. trop. 50:1-174

23.- Frey, D. (1965). Isolation of keratinophilic and other fungi from soils collected in Australia and N. Guinea. Mycol. 57:202-215

24.- Garg, A. K. (1966). Isolation of dermatophytes and other keratinophilic fungi from soils of India. Sabouraudia. 4:259-264

25.- Coudert, M. J.; Michel-Lebrun, J. \& Battesti, M. R. (1968). Recherches sur le micromycétes kératinophiles du sol dans la région lynnaise. Mycopath. Mycol. appl. 34:253-262

26.-Guzman-Chavez,R.; Segundo-Zaragoza, C.; CervantesOliveras, R. \& Tapia-Perez, G. (2000). Presence of keratinophilic fungi with special reference to dermatophytes on the haircoat of dogs and cats in Mexico and Nezahualcoyotl cities. In: Kushwaha, R K S \& Guarro, J (eds) Biology of dermatophytes and other keratinophilic fungi. Rev. Iberoam. Micol. Bilbao, Spain, pp. 41-44

27.- Sinski, J. T. \& Kelley, L .M. (1991). A survey of dermatophytes from human patientsin the United States from 1985 to 1987. Mycopathologia. 114:117-126

28.- Chabasse, D. (1988). Taxonomic study of keratinophilic fungi isolated from soil and mammals in France. Mycopath. 101:133-140

29.- Van Oorscht, C. A. N. (1980). A revision of Chrysosporium and allied genera. Stud. Mycol. 20:1-89

30.- Cano, J. \& Guarro, J. (1990). The genus Aphanoascus. Mycol. Res. 94:355-377

31.- de Hoog, G. S.; Guarro, J.; Gené, J. \& Figueras, M. J. (2000). Atlas of clinical fungi. ( $2^{\text {nd }}$ ed.). Centraalbureau voor Schimmelcultures. Utrecht, The Netherlands. 